\title{
Analysis of the Current Situation of Mongolian Railway and Its Future Development
}

\author{
Ulziinorov Gansukh ${ }^{1}$, Xu Ming ${ }^{2}$, Syed Ahtsham $\mathrm{Ali}^{3}$ \\ ${ }^{1}$ The Glorious Sun School of Business and Management, DongHua University, Shanghai, China \\ Correspondence: Ulziinorov Gansukh, The Glorious Sun School of Business and Management, DongHua \\ University, Shanghai, China.
}

Received: March 3, 2018

Accepted: April 4, $2018 \quad$ Online Published: April 23, 2018

doi:10.5539/ibr.v11n5p119

URL: https://doi.org/10.5539/ibr.v11n5p119

\begin{abstract}
The purpose of this article is to contribute the conceptual knowledge of the railway policy issue in Mongolia. The paper presented an overview of the current transport situation of Mongolian Railway. It analyzes the statistical indicators of freight and passenger traffic as well as capability analysis of the railway transport. Moreover, it highlights its further development prospects and its importance for country's economic. In last but not least, it formulates the future prospects of sustainable development of railway sector.

Findings of this research are: a) by analyzing statistic data the high correlation $(\mathrm{R}=0.87)$ between GDP and freight transportation of Mongolia has been confirmed. The type of cargo analyzed and the economically efficient type of cargo within Mongolia has been highlighted. b) The GDP and passenger turnover has a very weak relationship. c) In the regional context, Mongolia's transport statistics main indexes performance somewhat in the middle and there has room to increase the freight operation in the future.

The research method is based on the analysis of strategic documents, secondary data, including statistical data obtained from the Central Statistical Office in Mongolia, Statistical Office in UBTZ (Ulaanbaatar Railway Mongolian-Russian Joint-stock Company), OECD (Organization for Economic Co-operation and Development) official site, International Union of Railway (UIC) official site and World Bank official site.
\end{abstract}

Keywords: freight operation analysis, railway freight and passenger operation, railway of Mongolia, UBTZ (Ulaanbaatar Railway Mongolian-Russian Joint-stock Company)

\section{Introduction}

Since its establishment in 1938, the Mongolian Railway has been the most important transport sector within Mongolia. Every year, more than 23 million tons of cargo and 2.5 million passengers are transported through the railway in Mongolia. However, today's rapidly developing socio-economic condition and population demand more transport. The current capacity of railway does not meet to the growing demand of transportation and customers' needs. Therefore, this study intended to analyze the current condition of Mongolian railway, rail traffic trend and future prospects for development through the comparison and historical analysis methods.

The paper consists of following parts. First part reflects the overview of Mongolian railway's and its current capacity as well as existing railway operating parts. The second part discusses the Mongolian railway freight and passenger operation analysis. It also includes the freight operation's statistics and capacity analysis in the regional context within the Central Asian Regional Economic Cooperation organization (CAREC) country. Finally, it discusses the future development possible direction and investment plan of the railway of Mongolia.

\section{Overview of the Railway Operation in Mongolia}

\subsection{Railway's Brief Information}

The Mongolian Railway organization is one of the largest and most important transport organization in Mongolia. At present, the total length of the railway is $1815 \mathrm{~km}$, of which $1110 \mathrm{~km}$ runs from north to south, connecting European and Asian continent. 


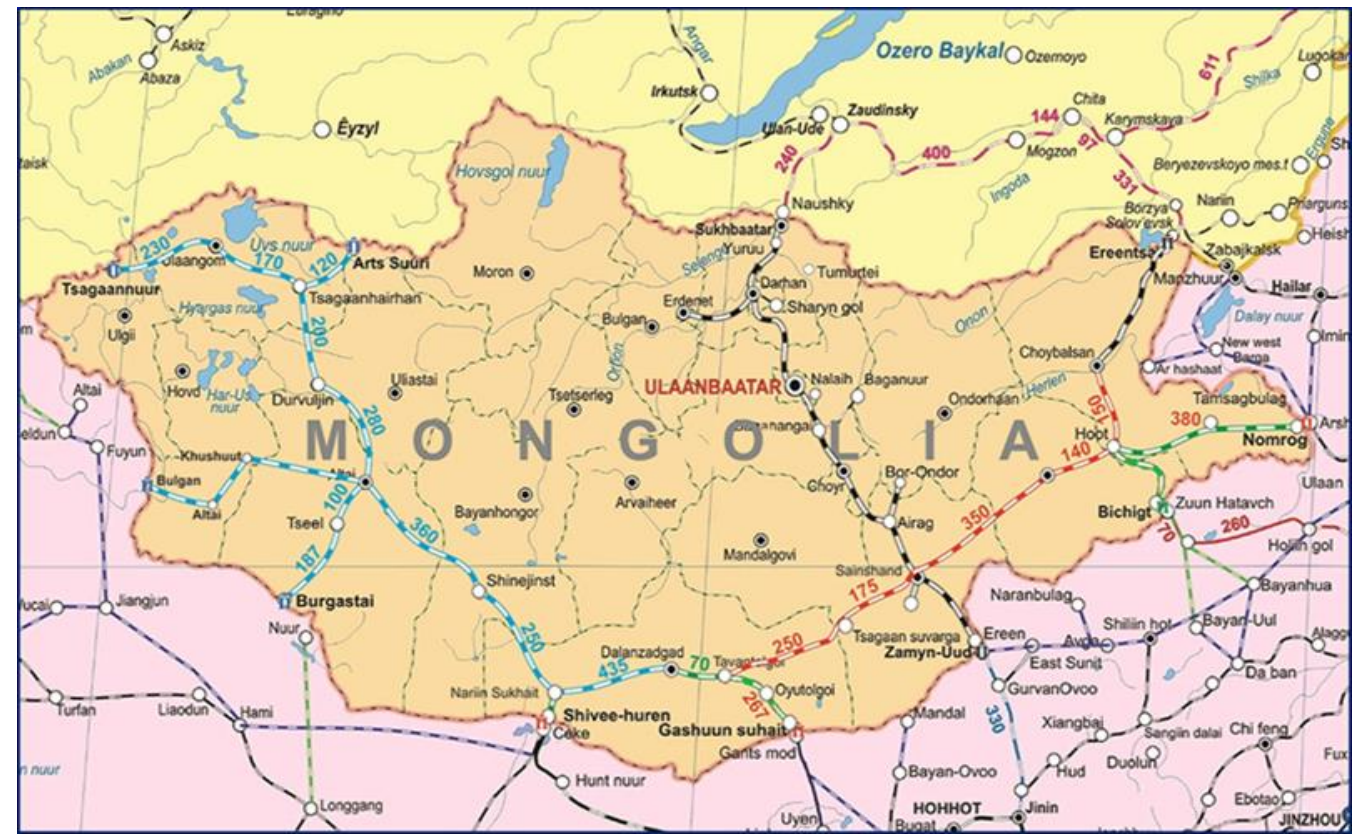

Figure 1. Map of the Mongolian railway system (the black one is an existing railroad system the blue, red, and green are the future plan)

Source: (MTZ, 2015)

Due to the geographical conditions, lack of direct access to the sea and vastness of the territory, the rail transport plays an extremely important role in Mongolia. The railway transport of Mongolia dates back to the first half of the $20^{\text {th }}$ century. The first railway of Mongolia was built in 1938 and was operated for $43 \mathrm{~km}$ length, from the "Nalaikh" coal mines to the capital. Construction of the Trans-Mongolian line began in 1947, reaching Ulan-Bator (the capital of Mongolia) from the north in 1950 and to the Chinese border in 1955. The Trans-Mongolian Railway follows an ancient tea-caravan route from China to Russia and connects to Ulan-Ude, on the Trans-Baikal (Trans-Siberian) railway in Russia, with the Chinese city of Jining, through Ulan-Bator in Mongolia (Trans Mongolian Railway, 2017). The operation was carried out in 1956. Thus one of the main transport corridors linking the European and Asian continents came into being. In 1949, it was organized by the Mongolian-Russian joint venture Ulan Bator Railway (UBTZ) based on an agreement between the government of the Mongolian People's Republic and the Soviet Union with an equal distribution of shares in the authorized capital (50\% to 50\%). The UBTZ is part of the Trans-Siberian rail network and part of the 4th corridor of the Central Asian Economic Cooperation.

\subsection{The Main Operation Parties of Railway in Mongolia}

To date, the main governing body of Railway sector in Mongolia is the Ministry of Road and Transport Development. Under the Ministry of Road and Transport Development, there is an organization named "Railway Traffic Control Center" which was established in 2013. The purpose of this organization is to coordinate the rail traffic within the public and private rail operators as well as regulating and managing the relations between them(Center, 2016). The most dominating and main railway carrier within Mongolia is UBTZ which is both infrastructure manager and the only transporter (carrier) operating on this infrastructure.

The Mongolian Railway State-Owned Shareholding Company (MTZ) is the 100\% state-owned company that was established in 2008 which owns locomotive and freight rolling stock fleets as well as logistic terminals, without rail tracks. In the future, the Government of Mongolia intends for MTZ to become a transporter and eventually an infrastructure owner taking the government shares in new railways (Drew, Enkhtaiva, Delgersaikhan, Enkhbayar, \& Bolatbeck, 2014).

The Bold Tumur Eruu Gol (BTEG) is a private company which was founded in 2001 and has an exploitation license for iron ore deposits. BTEG has built $85 \mathrm{~km}$ of railway line and owns locomotive and freight car fleets (Drew et al., 2014). At present, the rail sector of Mongolia has only government structure, but in the future, the private sector participation will be an increase since the extraction of mineral deposits and their exports going to be future prospects of a country. In section 3 , the new railway projects are discussed in detail. Table 1 shows the 
technical capacity of UBTZ. Today UBTZ is carrying out $78.5 \%$ of freight turnover and $27 \%$ of the passenger turnover in Mongolia (UBTZ, 2017a).

Table 1. The technical capacity of the UBTZ (in 2016)

\begin{tabular}{ll}
\hline Indicators & Units \\
\hline The total railway network & $1815 \mathrm{~km}$ \\
The length of the Trans-Mongolia railway & $1110 \mathrm{~km}$ \\
Rail Track Gauge & $1520 \mathrm{~mm}$ \\
Number of Stations & 75 \\
The train traffic system & Semi-automat \\
Total employee & 15800 \\
Annual transport capacity & $23-25$ million ton \\
Axle load & 23 ton \\
The train maximum speed: & \\
Freight train & $80 \mathrm{~km} / \mathrm{h}$ \\
Passenger train & $90 \mathrm{~km} / \mathrm{h}$ \\
Rolling Stocks Fleet: & \\
Number of locomotives & 138 \\
Number of freight cars & 3071 \\
Number of passenger cars & 292 \\
\hline Source: (UB
\end{tabular}

Source: (UBTZ, 2017a)

The total length of railway track is $1815 \mathrm{~km}$, of which Trans-Mongolian rail track is $1110 \mathrm{~km}$. Through this single railway track, overall railway traffic of Mongolia as well as international transit goods flow. In 2016, the UBTZ's annual cargo operation capacity was 23-25 million ton and the train maximum speed was $90 \mathrm{~km} / \mathrm{h}$, while the rail rolling stocks fleets are not enough to the increasing demands of cargo operation. As said in a study (UBTZ, 2017a) the most of the UBTZ's technology was developed in the early 1990s. This indicates the need of further development and investment projects to improve the railway sector. All these issues will be discussed in section 3.

\section{The Railway Operation Analysis of Mongolia}

\subsection{Railway Sector of Mongolia in the Regional Context}

Since Mongolia is located at the Central Asia region and a member of the Central Asian Regional Economic Cooperation organization, it is worth to investigate the railway of Mongolia in the regional context. Below is the railway statistics among the CAREC countries.

Table 2. Railway statistics of the CAREC country /data in 2015/

\begin{tabular}{|c|c|c|c|c|c|c|c|c|c|c|c|c|c|c|c|}
\hline \multirow[b]{2}{*}{ № } & \multirow[b]{2}{*}{ Country } & \multirow{2}{*}{\begin{tabular}{|l|}
$\begin{array}{l}\text { Surface } \\
\text { area } \mathbf{k m} 2\end{array}$ \\
thousands
\end{tabular}} & \multirow{2}{*}{\begin{tabular}{|l|} 
Population \\
millions \\
\end{tabular}} & \multirow{2}{*}{\begin{tabular}{|l|}
$\begin{array}{l}\text { Population } \\
\text { density }\end{array}$ \\
inhab/km2
\end{tabular}} & \multirow[b]{2}{*}{$\begin{array}{l}\text { Railway } \\
\text { company }\end{array}$} & \multicolumn{3}{|c|}{ length } & \multicolumn{2}{|c|}{ Stock } & \multirow{2}{*}{$\begin{array}{c}\text { Average } \\
\text { staff } \\
\text { /thousand/ }\end{array}$} & \multicolumn{2}{|c|}{ Freight } & \multicolumn{2}{|c|}{ Passenger } \\
\hline & & & & & & Total $/ \mathbf{k m} /$ & $\begin{array}{l}\text { Double } \\
\text { track } / \mathbf{k m} /\end{array}$ & $\begin{array}{l}\text { Electrified } \\
\text { track } / \mathbf{k m} /\end{array}$ & Locomotive & $\begin{array}{l}\text { Railway's } \\
\text { own } \\
\text { wagons }\end{array}$ & & $\begin{array}{l}\text { Tonnes } \\
\text { carried } \\
/ \mathrm{mln} /\end{array}$ & \begin{tabular}{|l} 
Tonne.km \\
/mln tonn- \\
km/
\end{tabular} & \begin{tabular}{|l} 
Passenger \\
carried \\
$/ \mathrm{mln} /$
\end{tabular} & $\begin{array}{l}\text { Passenger } \\
\text { kilometres } \\
/ \mathrm{m} \ln /\end{array}$ \\
\hline 1 & Russia & 17098 & 143.81 & 8 & RZhD & 85262 & 37869 & 43424 & 17511 & 63375 & 777.38 & 1329.01 & 2304759 & 1020.42 & 120413 \\
\hline 2 & Mongolia & 1564 & 2.96 & 2 & UBRW & 1822 & 0 & 0 & 138 & 3071 & 13.36 & 22.295 & 11462 & 3.31 & 1194 \\
\hline 3 & China & 9563 & 1370.84 & 143 & CR & 67212 & 33760 & 38521 & 19846 & 711968 & 2002.3 & 2294.1 & 1980061 & 1544.36 & 723006 \\
\hline 4 & Kazahkstan & 2725 & 17.51 & 6 & KZH & 14319 & 4911 & 4170 & 1816 & 55659 & 79 & 280 & 223583 & 21 & 16595 \\
\hline 5 & Afghanistan & & & & 0 & 0 & 0 & 0 & & & 0 & & 0 & 0 & \\
\hline 6 & Azerbaijan & 87 & 9.65 & 111 & $A Z$ & 2067 & 803 & 1232 & 326 & 18240 & 0 & 17.09 & 6210 & 1.89 & 494 \\
\hline 7 & Kyrgyzstan & 200 & 5.93 & 30 & KZD & 417 & 0 & & & & & 6.91 & 922 & 0.55 & 75 \\
\hline 8 & Pakistan & 796 & 188.93 & 237 & PR & 9255 & 2866 & 0 & 452 & 15452 & & 3.6 & 3301 & 52.95 & 20888 \\
\hline 9 & Tajikistan & 143 & 8.48 & 60 & TDZ & 620 & na & 0 & & & & 8.41 & 554 & 0.55 & 24 \\
\hline 10 & Turkmenistan & 488 & 5.37 & 11 & TRK & 3115 & na & 0 & & & & 26.84 & 11992 & 6.47 & 1811 \\
\hline 11 & Uzbekistan & 447 & 31.19 & 70 & UTI & 4191 & na & 702 & & & & 82.39 & 22686 & 17.12 & 3437 \\
\hline
\end{tabular}

Source: (International Union of Railways, 2015)

As shown in Table 2, Mongolia's population density $\left[\mathrm{inhab} / \mathrm{km}^{2}\right]$ is (2) the lowest within CAREC country, compared to other countries such as Pakistan (237), China (143) and Azerbaijan (111). However, the Kazakhstan, Russia, Turkmenistan, and Kyrgyzstan are also low population density countries.

Using above data, it is possible to calculate the railway operation capacity index for each country. The transport statistics main indexes (M. N. S. Office, 2008) are the total amount of transported cargo, freight turnover, a total amount of transported passenger, passenger turnover, wagon turnover, transferred ton per km, transportation income respectively. Among them the railway capacity indexes are worth to calculate and to compare country to country.

The freight turnover for one $\mathrm{km}$ railroad, passenger turnover for one $\mathrm{km}$ railroad, wagon turnover per $\mathrm{km}$ of railroad, average daily run of the locomotive per $\mathrm{km}$ of railroad are the capacity indexes which have been calculated in this part. The freight turnover for $1 \mathrm{~km}$ railroad is calculated as the freight turnover divided into the 
total length of the rail truck. Similarly, the passenger turnover for one km railroad is calculated. According to this methodology, the railway capacity indexes in 2015 has been calculated, among the CAREC countries, as shown in Figure 2.

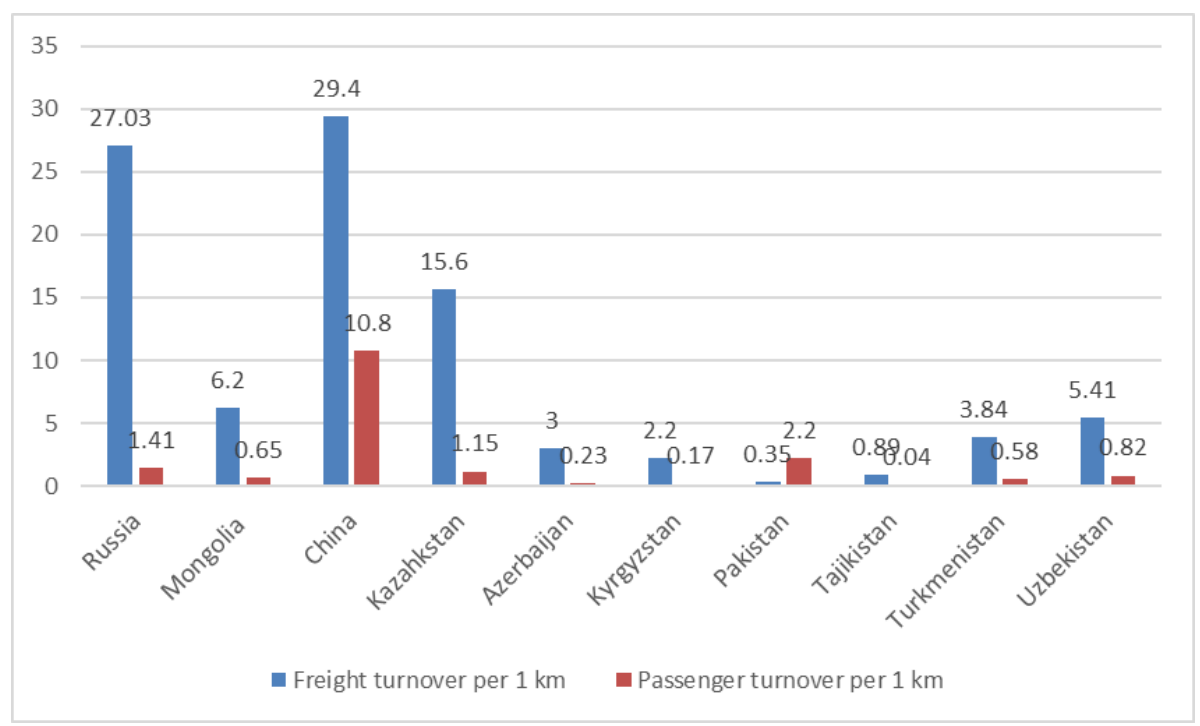

Figure 2. The railway capacity indexes within the CAREC countries

Source: (International Union of Railways, 2015)

From figure. 2 it can be seen that the freight turnover per km is highest in China, Russia, and Kazakhstan, while its low in Pakistan, Tajikistan, and Kyrgyzstan. The Mongolia and Uzbekistan are somewhat in the middle.

The passenger turnover per km is highest in the China, Pakistan, and Russia, on contrary Azerbaijan, Kyrgyzstan, and Tajikistan have lowest, but Uzbekistan, Mongolia, and Kazakhstan are comparatively in the middle position.

Additionally, the number of staffs per $\mathrm{km}$ of a railroad and the number of rolling stocks (total amount of locomotive and rail wagons) for per person have been analyzed. But due to the unavailability of whole data from some countries, the study used only for four countries. The number of staffs per $\mathrm{km}$ of railroad in Mongolia is 7 , in China 29, in Russia 9, and in Kazakhstan 6. The number of rolling stocks per persons, in Mongolia is 0.2; in China 0.3; in Russia 0.1; and in Kazakhstan 0.7. The number of stuff for per km railroad depends on the innovative technology level of railway and some other specific conditions.

From above calculation, the China and Pakistan railway passenger operations are more effective than other countries, while the carried freight is more in Russia and Kazakhstan than that in other countries. For Mongolia, the freight turnover and passenger turnover per $\mathrm{km}$ of railroad indexes have a different result. If compare to the CAREC country, Mongolia is in the somewhat middle position, after China, Russia, and Kazakhstan's indexes.

\subsection{The Rail Freight Operation Analysis of Mongolia}

The freight demand of rail transport may affect from economic conditions, expansion of the trade, regional market development, interdependence of the mining and industrial sectors, etc. Besides of demand, the supply also may affect to the transport market. The factors which affect to the supply can be railroad capacity, the amount of the rolling stocks (number of locomotives and wagons), loading and unloading terminal services etc. Although there has been a sufficient demand for cargo operation, it is limited by railroad real capacity. The throughput capacity of the railway, depends on the number of freight cars, the number of locomotives, the working condition of the terminal for loading and unloading cargo procedure, the number of stations, the rail truck length of the rail station etc.

In this part was analyzed the freight structure and future trends of a railway in Mongolia. From the Figure 5, it is clear that the in Mongolia's railway, the most effective and dominant operation is the freight transportation. 


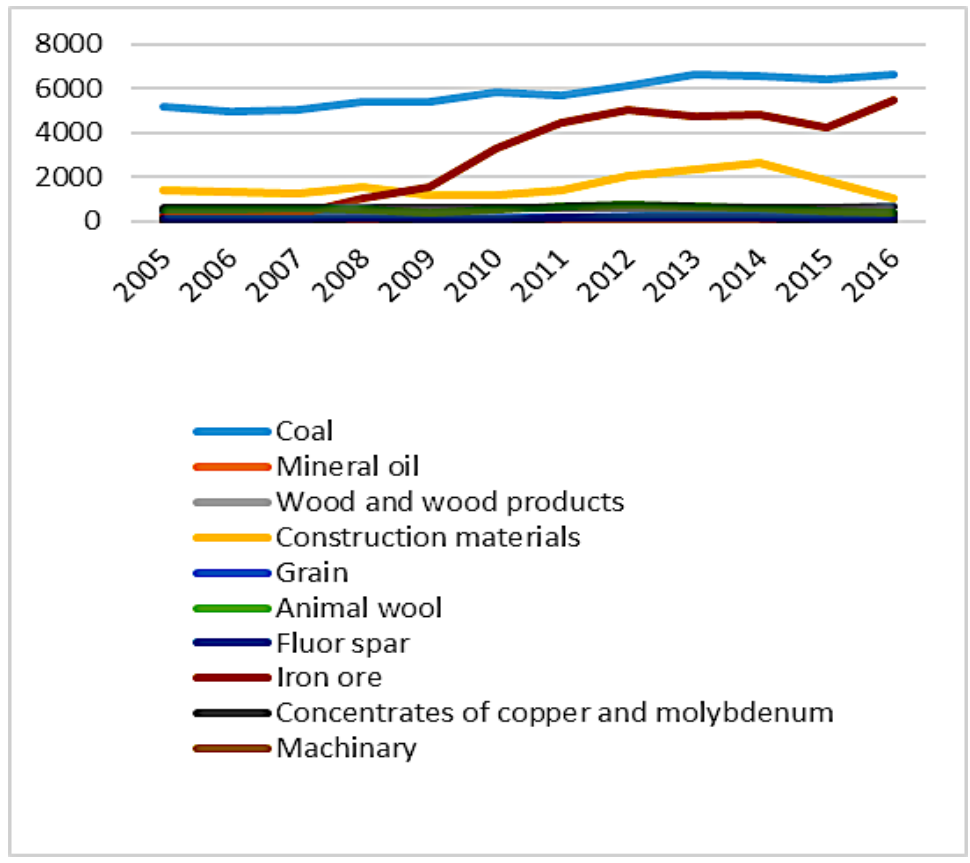

Figure 3. The type of the freights and its dynamic through the UBTZ from 2005 to 2016. Source: (U. Statistical Office, 2017)

From Figure 3, it can be realized that the countries most transported freights are iron ore, coal, copper, and construction materials. But due to the economic crisis of country, demands of the construction material have sharply decreased since 2014 and demands for the property have fallen. This crisis is still going on, and the real estate market is weak. However, due to the higher prices for coal and iron ore, the transportation is expected to increase. During the past decade, export volume of iron ore and copper concentrate to China have increased by more than $400 \%$.

Figure. 4 shows the freight transport structure of the UBTZ. The average annual growth rates between 2000 and 2016 indicate the following results: the total volume of freight traffic's growth rate is $4.96 \%$, in which import's growth rate is $4.7 \%$, export's growth rate is $13.9 \%$, domestic freight's growth rate is $2.25 \%$, and the transit freight's growth rate is $2.8 \%$.

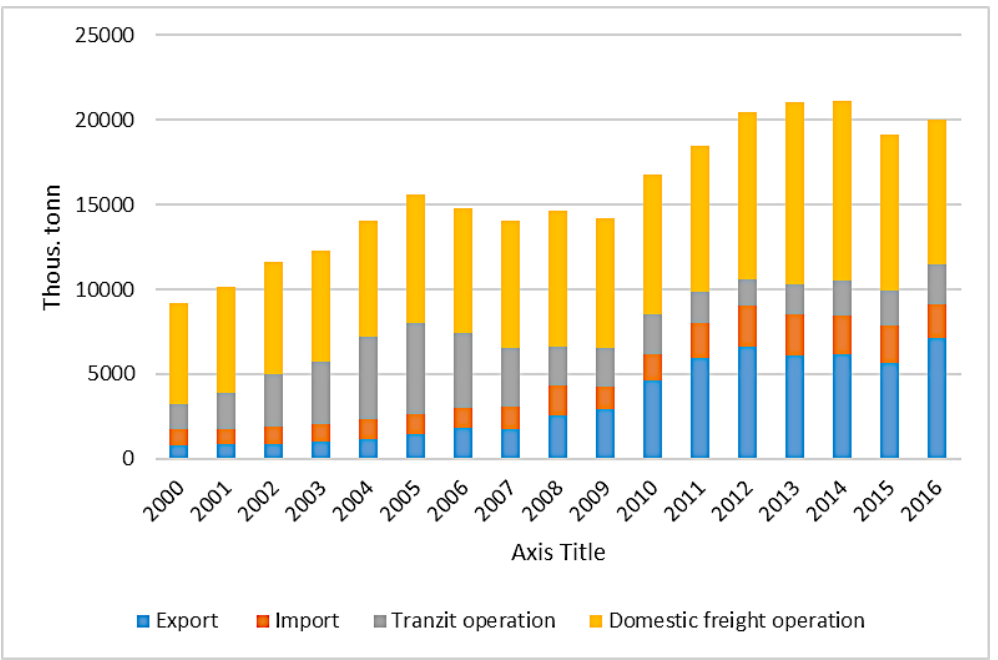

Figure 4. The freight transport structure operating through the UBTZ. Source: (U. Statistical Office, 2017)

The data from (figure.4) shows the export traffic rate is much higher than others. As in 2016, all Mongolia exports of $97.4 \%$ was exported to China (south) and only $2.58 \%$ was exported to Russia (north). From 2010, export sharply increased due to the export of mining products to China (south). As mentioned in the study (Otgonsuren, 2015) on March 21, in 2014, the Mongolian government made a decision to increase coal exports, 
within the framework of improving foreign trade, to build a standard gauge railroad which would connect Gashuunsukhait and the Ganqmod border port of entry in China. However, the data obtained from Ulan-Bator Railway Statistic office showed that the 70\% of imported goods are from Russia and 30\% from China. For the railway sector of Mongolia, transit traffic between China and the EU is strategically important(UBTZ, 2017a). So, collaboration with Russia's Railway as well as China's Railway can provide an opportunity to catch up freight flow.

Figure 4 shows that the traffic volume has been decreased since 2006. Before 2006 freight's annual growth was $21.2 \%$, after 2006 it has been decreased, and from 2006 to 2016 it was down (-5.79\%). For example, in 2015, transit transports from China to Europe, only $9 \%$ was transported via Mongolia. So, one of the main priority of UBTZ is to increase transit traffic volume.

The most of transit cargoes are directed from Russia to China. As in 2016, the $84 \%$ of transit cargo was transported from Russia to China and $15.9 \%$ of transit cargo directed from China to Russia. Therefore, not only railway authorities of Mongolia but also OSJD (Organization for Cooperation of Railways) should pay more attention to activate the container transportation from China via Mongolia to Russia and Europe and vise verse (OSJD, 2017).

\subsection{The Rail Passenger Operation Analysis of Mongolia}

As in many other countries, passenger operation of Mongolia's railway in a critical condition. Figure 5 shows that there is hardly any change in the rail passenger traffic within 16 years. Statistic show that (U. statistical Office, 2017), during the last few years, the passenger traffic trend has decreased. The highest period of passenger traffic was in 2007 when 4.5 million passengers have transported but as in 2016, it decreased to half, transported only 2.6 million passengers. There are many reasons for such decrease. For instance, the train's speed is slow as $80 \mathrm{~km} / \mathrm{h}$, the train timetable is unsuitable for passengers, and last few years was constructed a new motorways connecting between big cities and capital city as well as neighbor country's borders. In the future, the Government of Mongolia will pay more attention high-speed motorway constructing. Due to the new high-speed motorway citizens purchase of private vehicles increasing year by year.

From an economic point of view (Center, 2016), demands for passenger transportation depends on population growth, age structure, income growth, the development of other modes of transport, railway tariffs, and the throughput of the railways capacity, so on. In 2017, the Passenger Department of the UBTZ (UBTZ, 2017b) have conducted a survey from domestic rail passengers for all direction of UBTZ. The reason for the survey was to explore the passenger's satisfaction with current service quality level and highlight passenger's suggestion and opinion for further improvement of passenger service. Totally 1043 passengers have participated. However, valid answers got from 932 respondents.

The $65 \%$ of respondents were female, $35 \%$ were male and almost $50 \%$ of them aged between of 26 and 50 . The question "Why did you choose railway?" $44 \%$ of respondents chose reliable, $20 \%$ affordable, $23 \%$ convenient, and $10 \%$ good service, respectively. The respondent's complaints were: bad behavior of staff, lack of booking tickets, complicacy of buying tickets and somewhat necessity of more trains during the holiday time.

According to this survey and transport market demands as well as for improvement of passenger turnover, the UBTZ's Passenger Departments has a plan for series of work. For example, the new route of passenger trains has been opened recently. This is the Irkutsk-Ulaanbaatar tourist train new route. JSC Russian Railways and JSC UBTZ agreed on a new order of trains running in the Russia-Mongolia (OSJD, 2017). The traffic started its route in December 2017 from Ulaanbaatar. The train allows periodicity once a week from Ulaanbaatar to Irkutsk. This is expected to improve passenger traffic volume and efficiency of passenger service.

\subsection{The Rail Sector and the Macroeconomic Relationship Performance}

Mongolia has experienced a major mining boom. So, till 2012 because of the mining boom, in Mongolia a large number of mining products as a coal and iron ore are exported abroad through the railroad. The study said (Otgonsuren, 2015) GDP growth accelerated from $6.4 \%$ in 2010 to $17.5 \%$ in 2011 before slowing down somewhat to $12.3 \%$ in 2012 . High prices of copper and other commodities and expansionary fiscal policy have also contributed to the strong growth performance.

However, last five years GDP of Mongolia constantly slows down. The reasons may relate with an unstable policy condition and economic crisis of the country. The data (The World Bank, 2017) show, generally, GDP growth rate in Mongolia averaged $5.65 \%$ t from 1991 until 2016, reaching all-time high of $17.50 \%$ in the fourth quarter of 2011, and a record low of $-9.30 \%$ was in the fourth quarter of 1992. Although Mongolia was in an economic crisis between 2015 and 2016, it is expected to grow from 2020 (Center, 2016). 
For clarifying the relationship between GDP and a rail freight operation, the GDP per capita and railway main indexes were analyzed such as freight turnover and passenger turnover. Thus, some indication of how the Mongolian economy index and the demand for the passenger and freight transport have changed over time.

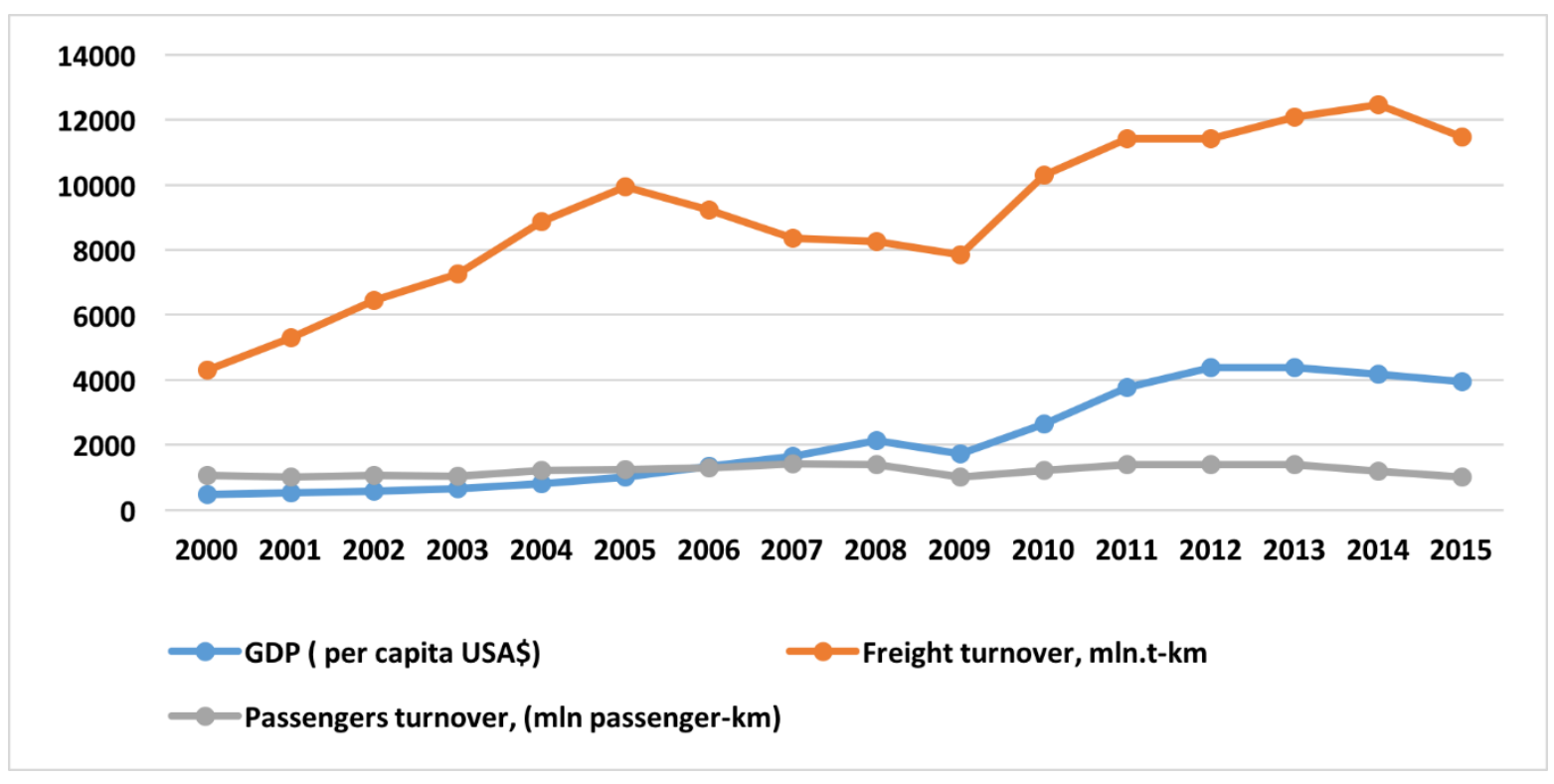

Figure 5. Trends of freight and passenger rail traffic and the GDP per capita of Mongolia period of 2000-2015.

Source: Data extracted from (U. Statistical Office, 2017), (The World Bank, 2017)

Figure. 5 shows that the passenger traffic does not present any significant changes during the period from 2000 to 2015. It is evident that the passenger transport is in a constant position, regardless of changes in the level of GDP. At the same time increasing trends of freight comparatively higher but does not always correspond to the line changes of GDP. It means that the role of freight transport as a contribution to GDP has varied over the analyzed period.

Using Excel Data Analysis Program, the correlation between GDP and freight transport have been calculated. The result shows that there is a strong correlation between GDP growth and domestic freight transport by rail. The correlation between 2000 and 2016, the railway freight and GDP correlation was R=0.87. The strong correlation between this allows the forecast for rail freight rates to be forecasted by GDP growth.

From another source (Center, 2016) it is also clear the GDP from 1990 to 2011 grew by about $70 \%$, while the domestic freight by rail was up by about $50 \%$.

\section{Further Development Pathway of Rail Sector (Sectors' Improvement Policies)}

\subsection{Some Issues Facing by Railway of Mongolia Today}

Although after the transition to the market economy of the country, the railway organization independently introduced some technological innovations. However, due to the insufficient funding, it was not fully reformed. As said in the recently formulated railway development strategy plan (Railway, 2016) in the future, double track along the Trans-Mongolian railway will be constructed, as well as the renovation and funding of all entities of the UBTZ is expected. After all, the train speed will be increased to at least $150 \mathrm{~km} / \mathrm{h}$, and the rail transportation capacity increment will reach up to 53.6-73.7 million ton per year (maximum performance will reach up to 100 million tons per year). The study (UBTZ, 2017a) mentioned that totally 1,5-4,4 billion US dollars are needed for the investment of UBTZ's new development project.

Table 3 shows the direction and the percentage of the investments. The foremost important direction is the infrastructure construction, after that rolling stock fleets renovation. Today, the total amount of freight car fleet within Mongolian rail sector is 6,501 units, of which 50\% belongs to the UBTZ, $46 \%$ to the BTEG and $3.76 \%$ to the MTZ respectively(Center, 2016). 
Table 3. The direction and percentage of the planned investments

\begin{tabular}{cc}
\hline Investment direction & Percentage of the investment \\
\hline Infrastructure construction & $80.3 \%$ \\
Rolling stock fleet renovation & $5.4 \%$ \\
Cargo operation and logistics & $1.8 \%$ \\
Passenger operation and service & $1.4 \%$ \\
Others & $11.1 \%$ \\
\hline
\end{tabular}

Source:(UBTZ, 2017a)

Although the rail car fleets depreciation is the main problem, the depreciations degree of car deferent road to road. Study conducted from the Rail Traffic Control Center (Center, 2016) mentioned that, for UBTZ car fleets are comparatively poor condition, $75 \%$ of them have been worked more than 25 years, for MTZ, car fleets consists of rail cars that have run 6 to 10 years, for BTEG 50\% of total car fleets have worked more than 25 years.

\subsection{New Railway Projects}

Due to the rapid development of the mining sector of our country, the demand for rail transportation and freight traffic is growing year by year. According to the government resolution No.32 approved in 2010, the government of Mongolia affirmed the "State Railway Policy". According to this document, it will be a gradual construction of 5,683.5 km of rail in Mongolia (MTZ, 2015) and it is expected that with the exploitation of new railways, exports commodities will reach up to 50 million tons per year. Due to such projects, it will extract 20-40 million tons of coal and coking coal from the Tavantolgoi deposits each year; 1.8 million tons of copper concentrate from Oyu Tolgoi deposit; 6 million tons of iron deposit, and 240 thousand tons of iron products from the Darkhan metallurgical plant each year.

The demand for shipping will be 2.5-5.5 times more. When starting to exploit large mines, there will be a flow of traffic, directed to the central location of deposits, as well as traffic from these centers to other regions of the country. The mining industry of Mongolia is actively participating in the Chinese market, and in the coming years, there is a growing demand for freight transport. At present, our country is able to export 100 million tons of coal per year, but in 2016, it exported only 19.5 million. This is an obvious example of lack of logistics and transport capacity that influence the country's economy(Center, 2016).

According to the demands of development of the mining industry Southern Mongolian, the Umnogovi aimak has become a special place (the place where a large mining deposit was discovered). The study (Zorigt.M, 2016) mentioned about the new railway projects, as it will construct the double tracks as well as other new branch railroads connecting to the mining deposits and neighboring countries border. These will be the starting point to the railway's further developments. Also, the study (UBTZ, 2017a) indicated, Government of Mongolia (GOM) is planning to build and finance $1,800 \mathrm{~km}$ of a railroad in two stages which will link the mineral deposit sites in the Mongolian desert steppe with Russia via Choibalsan and Sainshand.

The study (Otgonsuren, 2015) indicates that in October 2014, the Mongolian government announced its intention to build large-scale transport infrastructure projects to boost mineral shipments from Russia to China via the Trans Mongolian Railway. A $542 \mathrm{~km}$ long line will be constructed from Erdenet to Ovoot. Approximately 1.3 billion US dollars will be directed to the construction of the 542-kilometer Erdenet-Ovoot railway. This new railway will bring major economic and social benefits to Northern Mongolian provinces as economic development and regional integration is fast-tracked. 


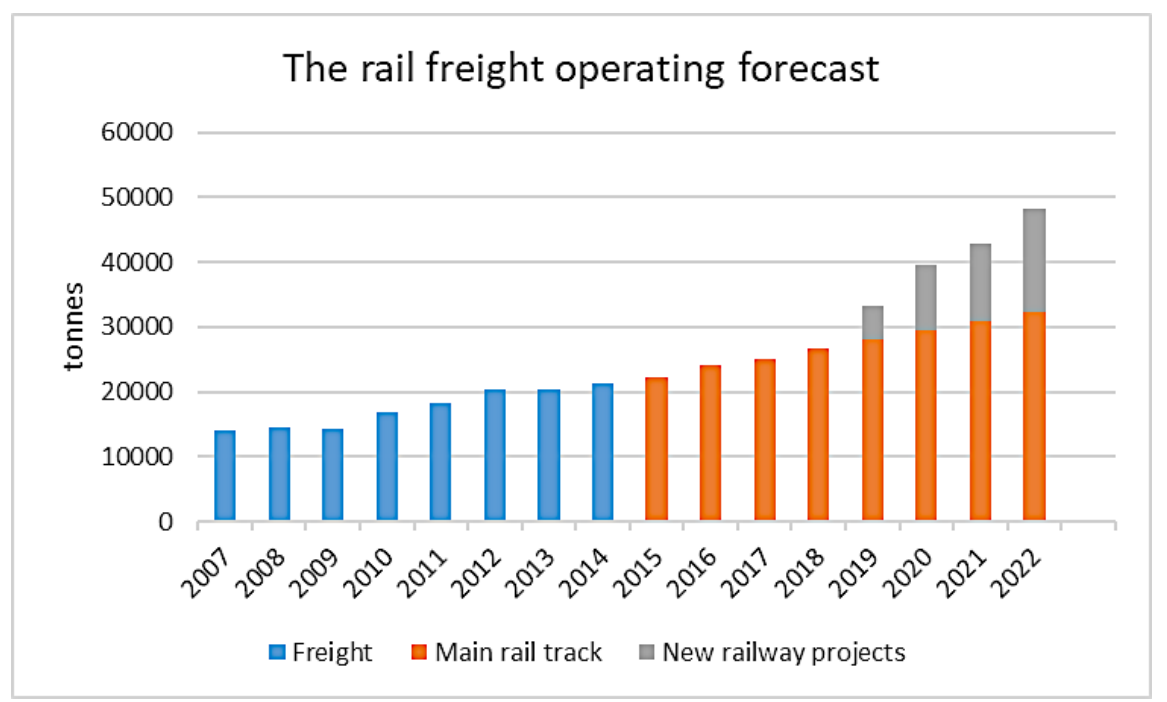

Figure 6. The rail freight forecast up to 2022

\section{Source:(Center, 2016)}

Figure 6. indicates the rail freight forecast analysis. As it is expected that in 2022, freight operation within Mongolia will be totally 32.2 million tons of cargo without new projects. However, with new projects the 48,2 million tons of cargo per year as well as with $22-28$ pairs of trains per day will be transported, which is twice as much as of now (the average railway network is 11-14 pairs of train per day).

\subsection{The Economic Corridor Building Process}

The goal of the creating the Economic Corridor is to provide the conditions for the development and expansion of trilateral cooperation between the People's Republic of China, Mongolia and the Russian Federation. The joint projects aimed at increasing the trade turnover, ensuring product competitiveness, facilitating cross-border transportation, and developing an infrastructure. The economic corridor program includes railway and road, air transport spaces, gas and oil pipelines, power lines and high-speed motorway networks. As said (Zorigt.M, 2016) the $70-80 \%$ of the economic corridor programs related to the transport industry. Altogether 32 projects will be implemented, 8 of which directly related to the railway development issue. The purpose of the policy for developing the rail transportation system pursued by the Mongolian Government is intended to become independent of a single market for exporting mining products.

In the research article (Otgonsuren, 2015) mentioned that the project named "The Silk Road Economic Belt and 21st Century Maritime Silk Road", which was developed in March 2015 by the National Development and Reform Commission of China, the Ministry of Foreign Affairs and the Ministry of Commerce of China, stated following; from the Chinese side there are roads and railroads to the north of Beijing, Tianjin, Hebei Province, the Inner Mongolia Autonomous Region, and the three Northeast provinces, and the border crossing-points with Mongolia and Russia are included in the economic corridor of the three countries.

\section{Conclusion}

On the basis of above research the conclusions are as in following:

Firstly, the analysis based on the statistical data shows that the current capacity of Mongolia's railway cannot meet the growing demands of transport market. For Mongolia, most effective type of railway transportation is the freight operation. However, due to the deprecating condition of the rail rolling stock fleets and insufficient development of railway infrastructure which is related with less investment and few high tech used for many years, current railway system in Mongolia is greatly lacked to transportation which needs to economic development in Mongolia.

Secondly, the analysis of the railway capacity indexes within CAREC country shows that Mongolia's railway capacity indexes such as freight and passenger turnover per km of railway are not very high but in the middle position among CAREC country. However, in the future, if it would be realized some sounding projects as economic corridor initiatives between Mongolia China and Russia, new railway constructing projects etc, then Mongolia has room to increase cargo operation in the international level thereby to strengthen the position in the regional context. 
Thirdly, according to the passenger operation analysis, Mongolia's railway facing the problems with ineffective passenger transportation. However, OSJD (Organization for Cooperation of Railways), as well as Mongolia's main rail operator UBTZ, pay special attention to passenger transport improvement issue, as a currently opened new route (OSJD, 2017) for tourist train between the capital of Mongolia and Russian city Irkutsk that expected to be increase transported passengers. Although the passenger transportation is an ineffective type of rail transportation in Mongolia, in the future, through the developing some effective management systems and maintaining new technology it would give the possibility to upgrade passenger service thereby to attract more customers.

Fourthly, as a key to improving the economy of Mongolia, the development of the mining sector is a priority for Mongolian Government. The transportation and exporting of mining products highly depend on country's railway development level. Today Mongolia's mining sector is able to transport and export only $20 \%$ of all extracted mining products (Center, 2016). Therefore, the construction and operation of new railways are the main tasks to the Government. Based on this situation the Government of Mongolia, as well as Railway Authorities, have made series of initiatives.

\section{References}

Center, R. C. (2016). The Feasibility Study of Rail Traffic Control Center. Ulaanbaatar, Mongolia: Railway Traffic Control Center.

Drew, J., Enkhtaiva, J., Delgersaikhan, N., Enkhbayar, Z., \& Bolatbeck, R. (Railway and M. T. P. I. C. D. (2014). Rail Infrastructure Tariffs. Enabling Private Sector - Development in Mongolia's Railway Sector. Asian Development Bank (ADB).

International Union of Railways. (2015). Railway Statistics: 2015 Synopsis, 33(0), 2015-2016. Retrieved from https://uic.org/IMG/pdf/synopsis_2015_print_5_.pdf

MTZ. (2015). The new railway project. Ulaanbaatar, Mongolia.

Office, M. N. S. (2008). The statistic methodology of transport. Ulaanbaatar: The National Statistic Office of Mongolia.

Office, U. statistical. (2017). Transportation Indexes of the UBTZ JSC. Ulaanbaatar.

OSJD. (2017). Protocol.Meeting of Group II of the coordination of the timetables for the movement of passenger trains, schemes for the formation of trains and the provision of their wagons in international traffic for 2018-2019. The Socialist Republic of Vietnam, Halong.

Otgonsuren, B. (2015). Mongolia-China-Russia Economic Corridor Infrastructure Cooperation. Erina Report, 127(12), 4. Retrieved from http://www.erina.or.jp/wp-content/uploads/2015/02/er127_tssc.pdf\#page=6

Railway, R.-M. J. S. C. (2016). Strategic Development Plan JSC 'Ulan Bator Railway' for the period until 2020. Ulaanbaatar, Mongolia.

The World Bank. (2017). GDP(current US\$) Mongolia. Retrieved from https://data.worldbank.org/indicator/NY.GDP.MKTP.CD?locations=MN

Trans Mongolian Railway. (2017). In Wikipedia, the free encyclopedia. Retrieved 20 July 2010, from https://en.wikipedia.org/wiki/Trans-Mongolian_Railway

UBTZ. (2017a). The Program of modernization and developmentof the Mongolian-Russian Joint-Stock Company Ulaanbaatar Railway for the period untill2030/project. Ulaanbaatar.

UBTZ, P. S. D. (2017b). The summary of the rail passenger survey in 2017. Ulaanbaatar, Mongolia.

Zorigt.M. (2017). The Economic corridors should be confirmed in the first half of the current year. Retrieved from http://www.mongolianminingjournal.com/content/62256.shtml

\section{Copyrights}

Copyright for this article is retained by the author(s), with first publication rights granted to the journal.

This is an open-access article distributed under the terms and conditions of the Creative Commons Attribution license (http://creativecommons.org/licenses/by/4.0/). 